\title{
ELECTRONIC GOVERNMENT AND ONLINE TASKS: TOWARDS THE AUTONOMY AND EMPOWERMENT OF SENIOR CITIZENS
}

\author{
Administración electrónica y trámites online: \\ hacia la autonomía y el empoderamiento de las
} personas mayores

Leopoldo Abad-Alcalá, Carmen Llorente-Barroso, María Sánchez-Valle, Mónica Viñarás-Abad and Marilé Pretel-Jiménez

Nota: Este artículo se puede leer en español en:

http://www.elprofesionaldelainformacion.com/contenidos/2017/ene/04_esp.pdf
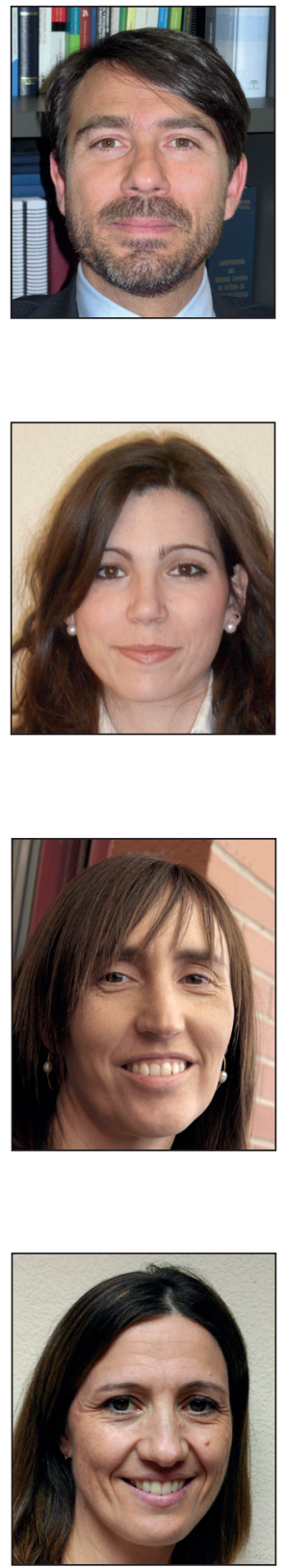

Leopoldo Abad-Alcalá graduated in Journalism from Universidad Complutense de Madrid (UCM) and Law from Universidad Nacional de Educación a Distancia (UNED), and received a PhD in Information Sciences (UCM). Researcher head of the projects Digital divide and older people: Media literacy and e-inclusion (CSO2012-36872); and Elderly people, e-commerce, and electronic administration (CSO2015-66746-R), both of the National $R+D+i$ Plan. He is also a researcher of the Digital vulnerability project (HUM2015/HUM-3434 -Provuldig-CAM). Author of more than 30 publications. Guest lecturer at European, USA, and Ibero-American universities, he combines teaching and research work at CEU San Pablo University.

http://orcid.org/0000-0002-4194-6404

abad.fhm@ceu.es

Carmen Llorente-Barroso holds a PhD in Advertising and Audiovisual Communication from Complutense University of Madrid (UCM) and has devoted part of her career to research in various projects. She has published several articles in indexed journals and regularly participated in professional conferences. Her lines of research are focused on the study of creative and strategic indicators to achieve an effective communication level, particularly oriented to vulnerable audiences. An active member of CSO2015-66746-R, S2015/HUM-3434 (Provuldig-CAM), R14, CEU-Citec and Asocrea, she combines teaching at CEU San Pablo University with research.

http://orcid.org/0000-0001-7710-0956

carmenllore@gmail.com carmen.llorentebarroso@ceu.es

María Sánchez-Valle holds a PhD from Universidad Pontificia de Salamanca. She is a lecturer at CEU University in Madrid, Spain. She is the director and the coordinator of the Master in public relations and event management. She is a member of two research teams devoted to online communication and the vulnerable public. She is a researcher in the Digital vulnerability project (HUM2015/HUM-3434 -Provuldig-CAM) and Auctoritas doméstica, capacitación digital y comunidad de aprendizaje en familias con menores escolarizados (CSO2013-42166-R). http://orcid.org/0000-0003-1497-2938

mvalle.fhum@ceu.es

Mónica Viñarás-Abad holds a PhD in Communication from Complutense University of Madrid (Spain). She is an adjunct professor at Universidad CEU San Pablo. Author of several books, including Basic dictionary of communication and also of various articles in scientific journals. Her research is focused on the strategic management of corporate communication and its social effects. She is a researcher of the project CSO2015-66746-R, S2015/HUM-3434 (Provuldig-CAM), and belongs to several professional associations such as AEIC, Dircom, Icono 14, and AIRP.

http://orcid.org/0000-0001-8792-5927

monica.vinarasabad@ceu.es 


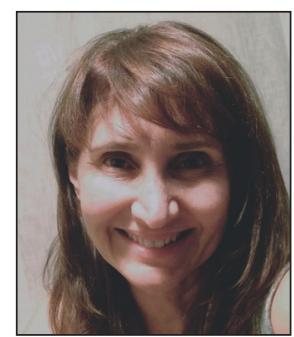

Marilé Pretel-Jiménez holds a PhD in Communication from Complutense University of Madrid (Spain), and a master's in Marketing, Communication, and Commercial research from IDEM. She is a lecturer and the vicedean at CEU San Pablo University. She has more than 20 years of experience in advertising \& marketing and has worked as a service client director in the international companies $Y \& R$, Tapsa, and TBWA. Her research focuses on digital, social media, consumer behavior, and branding. Active member of the Digital vulnerability project (HUM2015/HUM-3434 -ProvuldigCAM).

http://orcid.org/0000-0001-6775-047X

mapretel.fhm@ceu.es

University CEU San Pablo, Faculty of Humanities and Communication Sciences Po de Juan XXIII, 6. 28040 Madrid, Spain

\section{Abstract}

The use of the Internet by the senior citizens in order to manage operations with the government and companies requires further study. The objective of this work is to take a close look at the reasons why older people make limited use of e-administration and online procedures. Using a qualitative methodology, based on four focus groups, we analyze the motivations and problems they find when using such procedures. The results indicate acceptance of electronic resources for simple and routine tasks due to the speed and convenience they offer, which simultaneously promotes the independence and empowerment of older people. However, there is a series of factors which have a negative effect on their use, and these must be dealt with in order to favor greater digital inclusion of this age demographic.

\section{Keywords}

E-government; E-administration; Senior citizens; Empowerment; Internet; Online tasks; Online procedures; Digital inclusion; Active aging; Elderly; Older people.

\section{Resumen}

El uso de internet por parte de las personas mayores para realizar gestiones con la administración pública y las empresas no ha sido suficientemente estudiado. El objetivo de este trabajo es profundizar en las razones del empleo limitado de la administración electrónica y los trámites online por parte de los internautas mayores. A través de una metodología cualitativa, basada en cuatro grupos de discusión, se analizan las motivaciones y frenos en la utilización de tales trámites. Los resultados indican una aceptación del empleo de los recursos electrónicos para las tareas más rutinarias y sencillas debido a la rapidez y comodidad que proporcionan, al tiempo que fomentan la autonomía y el empoderamiento de las personas mayores. Si bien, se plantea una serie de aspectos que condicionan negativamente su utilización, sobre los que se debe incidir para favorecer una mayor inclusión digital de este grupo poblacional.

\section{Palabras clave}

Administración electrónica; Personas mayores; Empoderamiento; Internet; Administración electrónica; Trámites online; Inclusión digital; Envejecimiento activo; Mayores; Tercera edad.

Abad-Alcalá, Leopoldo; Llorente-Barroso, Carmen; Sánchez-Valle, María; Viñarás-Abad, Mónica; Pretel-Jiménez, Marilé (2017). "Electronic government and online tasks: Towards the autonomy and empowerment of senior citizens". El profesional de la información, v. 26, n. 1, pp. 34-42.

https://doi.org/10.3145/epi.2017.ene.04

\section{Introduction}

The census data published by the National Institute of Statistics (INE) in July 2015 confirm the aging of the population in Spain, as persons aged over 65 account for $17.57 \%$ $(8,156,702)$ of the total population $(46,423,064)$, and those aged over 80 account for $5.9 \%(2,752,057)$. The projections for Spain for the 2009-2049 period by the INE see an increase in the dependency ratio from $47.8 \%$ at present to $89.6 \%$ (INE, 2010, p. 3). In view of this situation, and based on the ubiquity of information and communications technology (ICT) in citizens' lives, we look at how to optimize the use of ICT for this age group to improve their personal and social situation. Considering specifically senior citizens' interaction with e-government in the latest INE survey, of the total number of Internet users in the last 12 months, while $63.4 \%$ contacted the authorities via the Internet, people aged between 65 and 74 were only 39.7\% (INE, 2015).

The initial assumption of this research is to consider that the limited use of e-government by senior citizens is not only due to technical or operational limitations but is also caused by motivational and psychological factors (cognitive, emotional, and behavioral factors).

The scientific bibliography on the matter has not been particularly extensive, although there are papers such as that of Ebbers, Pieterson, and Noordman (2008) which proposes strategies for the use of the various channels of communication by the government depending on the type of task that the citizen wishes to perform, or which deal specifically with the experience in a particular country, confirming the limited use of e-government by senior citizens albeit without 
considering the reasons (Colesca; Dobrica, 2008). Studies confirming much of our initial assumptions are those by:

- Belanger and Carter (2009), which states that the digital divide that already exists depending on criteria such as race, income level, education level, or age increases when it comes to the use of e-government;

- Phang et al. (2006), which looked at certain factors that shape the use of e-government services, such as security, the promotion of self-fulfillment in cases of successful use or efforts to mitigate so-called "technological anxiety".

Also, there are two papers that assess the properties that government websites must have in order to be "senior-citizen-friendly" (Becker, 2005; Lara-Navarra; Martínez-Usero, 2003). Contributions regarding the situation of e-government in the European context have been more related to specific aspects of e-government than to the accessibility of its services for senior citizens (Fernández-Ecker, 2010).

\section{Methodology}

Focus groups have been considered the most appropriate method to study the use of e-government by senior citizens, since this is one of the most used qualitative techniques for obtaining perceptions on a particular area of interest (Krueger, 1991) and analyzing a relatively large number of people in a short period of time (Vallés, 1997). It allows access to what the participants think; provides answers to how and why they have developed their conceptions of the subject-matter of the study (Kitzinger, 1995, p. 299); offers mutual support for the expression of common sentiments in the groups which can sometimes be prohibited by public opinion (Kitzinger, 1995, p. 300, p. 302); facilitates the discursive reconstruction of the section of society to which the participants belong, according to what ought to be, i.e., the rule with regard to what one considers to be the phenomenon to be investigated (Callejo-Gallego, 2002; Grønkjaer et al., 2011, p. 16.).
This multiplicity of viewpoints and emotional processes within the context of a group helps to explore or generate hypotheses (Powell; Single, 1996), since the main strength of this research technique is the capacity to observe the scope and nature of the respondents' agreements and disagreements. Multiple explanations of their behavior and attitudes would be difficult to identify using other research techniques (Morgan, 1996, p. 139; Gibbs, 1997, pp. 2-3).

To this end, a standardization was performed through homogenization of the questions and procedures to be used in all groups to achieve a high level of comparability among them (Morgan, 1996, p. 142-143). A thematic script to steer the debate was designed, which was sufficiently open so as not to interfere with the group dynamics or shape the results, but comprehensive enough for accurate coverage of the question.

Insufficient use by senior citizens of egovernment is due to technical or operational limitations and to motivational and psychological factors

A methodological design was considered, underpinned by four discussion groups of between five and eight participants. Small groups were selected because they were appropriate for matters involving some emotional commitment and generating high levels of interaction, critical to the group within society that was studied (senior citizens) and the results sought. The focus group's duration varied depending on their wealth and the profusion of arguments, always guided, but not conditioned or determined, by the expert researcher who moderated them.

For the selection of the sample, the focus was on homogeneity within each group in order to take advantage of

Table 1. Technical details of the discussion groups

\begin{tabular}{|c|c|c|c|c|}
\hline & Group A & Group B & Group C & Group D \\
\hline Number of members & 5 people ( 4 women and 1 man) & $\begin{array}{l}9 \text { people ( } 6 \text { women and } 3 \\
\text { men) }\end{array}$ & $\begin{array}{l}6 \text { people ( } 4 \text { women and } \\
2 \text { men) }\end{array}$ & $\begin{array}{l}8 \text { people ( } 2 \text { women and } 6 \\
\text { men) }\end{array}$ \\
\hline Age range & 62 to 68 & 62 to 75 & Over 65 & 69 to 73 \\
\hline Residence & Guadalajara (Castilla La Mancha) & $\begin{array}{l}\text { Paracuellos del Jarama } \\
\text { (Madrid) }\end{array}$ & Madrid & Barcelona \\
\hline Level of education & $\begin{array}{l}\text { Heterogeneous ( } 3 \text { with univer- } \\
\text { sity education and } 2 \text { with aver- } \\
\text { age education) }\end{array}$ & $\begin{array}{l}\text { Heterogeneous ( } 3 \text { with } \\
\text { university education and } 6 \\
\text { average education) }\end{array}$ & University education & $\begin{array}{l}\text { Heterogeneous ( } 7 \text { with } \\
\text { university education and } 1 \\
\text { with average education) }\end{array}$ \\
\hline $\begin{array}{l}\text { Socioeconomic } \\
\text { profile }\end{array}$ & Medium & Medium & High & Medium/high \\
\hline Professional profile ${ }^{1}$ & $\begin{array}{l}\text { Managers and lower ranking } \\
\text { professionals. Lower ranking } \\
\text { technicians and } \\
\text { supervisors }\end{array}$ & $\begin{array}{l}\text { Average and lower ranking } \\
\text { professionals }\end{array}$ & Managers & Managers \\
\hline Current occupation & All retired & All retired & 5 retired and 1 active & All retired \\
\hline $\begin{array}{l}\text { Link between } \\
\text { members }\end{array}$ & $\begin{array}{l}\text { Fellow English course students } \\
\text { (Guadalajara adult school) }\end{array}$ & $\begin{array}{l}\text { Fellow participants in cul- } \\
\text { tural activities and neighbors }\end{array}$ & $\begin{array}{l}\text { Members of a professional } \\
\text { club }\end{array}$ & Unrelated \\
\hline Selection criteria & Internet users aged over 60 & Internet users aged over 60 & Internet users aged over 60 & Internet users aged over 60 \\
\hline $\begin{array}{l}\text { Duration of } \\
\text { discussion }\end{array}$ & 01:20:55 & $1: 12: 17$ & $1: 15: 14$ & $1: 47: 50$ \\
\hline
\end{tabular}


people's shared experiences (Kitzinger, 1995, p. 300; Gibbs, 1997, p. 4) and on segmentation because it allows:

- the construction of a comparative dimension throughout the research project, including data analysis;

- facilitation of discussions by ensuring participants are more similar to each other (Morgan, 1996, p. 143-144).

Accordingly, the persons making up the sample were the result of a basic selection criterion: persons aged 60 or above who used the Internet. Participants were also:

- of both genders;

- middle or upper-middle class;

- with differing educational and socioeconomic levels;

- living in urban areas of varying sizes; and

- with an interest in maintaining an active life (the link between them is based on their motivation to learn).

The discussions were audio-recorded and subsequently transcribed in order to facilitate a fundamentally interpretive analysis of the discursive content. The content of all the discussions was gathered together and compared, and a global analysis was performed seeking similarities and differences in the thematic areas addressed and examining how they relate to the variables within the population under analysis without focusing on specific parts of the matter addressed (Onwuegbuzie et al., 2009, p. 4; Vallés, 2002).

We performed the data analysis process from a hermeneutic perspective, considering that the interview data are treated as a text that presents a complex network of internal relationships so that no aspect can be understood independently and without reference to the text taken as a whole. Thus, we have included several extracts of the participants' statements that identify noteworthy sections of the discussion.

The final phase, that is of an inferential nature, consisted of extracting and explaining the most significant aspects of the

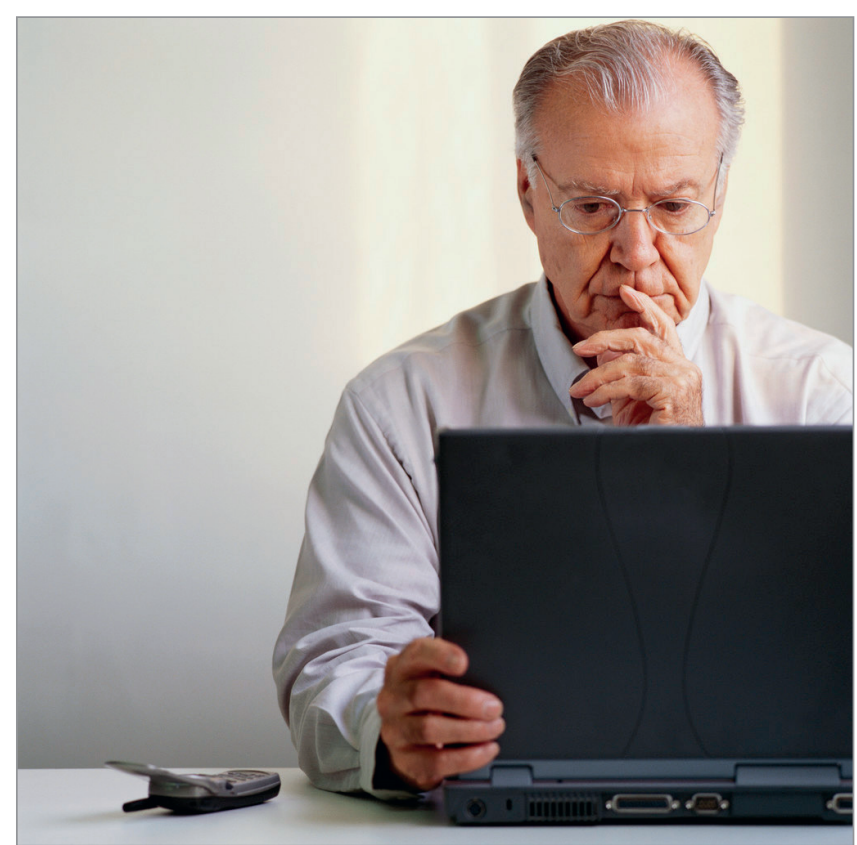

https://goo.gl/5DOXKe experiences reported by participants relating to the purposes of the research. The intention at this stage was not simply to examine the content of the speech, but to consider what the participants were doing with their utterances, as the explanatory and objective analytical position on the uses and needs of senior citizens with respect to government was adopted, considering that speech is not a simple container of meaning, but is functional in itself, when it involves agreeing, blaming, narrating or any of the other ways in which participants "do things with words" (Turner; Turner; Vande-Walle, 2007, p. 290). Thus, following the considerations of Gil-Flores, García-Jiménez, and Rodríguez-Gómez (1994, p. 192), categories were identified responding to thematic units on the question analyzed.

The online administrative function most used by senior citizens is medical appointments

\section{Results}

In the four discussion groups there was some agreement regarding an interest in the use of the Internet for conducting formal tasks with the government and other types of administrative activities, which contributes to active and healthy aging and expedites some tasks that they have to perform. The results were classified into five thematic categories based on the research results sought. There were also interesting discrepancies on some matters that could provide food for thought among social organizations.

\subsection{Senior citizens and online government (e-gover- nment)}

Online administrative activities are not the most common activities performed by senior citizens, although some of these activities have a great deal of potential due to their convenience and those who perform them find them really useful.

The administrative function that is most frequently completed is the request for doctor's appointments, because they find it convenient, fast, and flexible. Then come the other applications for making appointments in advance, such as the renewal of the National Identity Card (DNI). There are few differences in this respect, although a participant of group $D$ indicated a preference for the telephone:

"I don't tend to deal with medical issues using the Internet because I like to choose" or "one time when I tried to make an appointment I gave up" (group D).

Tasks relating to public bodies and bureaucratic tasks are perceived as being more gender-specific, in particular the case of personal income tax declarations:

"I'm the husband so I have to do it [the tax declaration]" (group A).

This is something that also happens with bank statements and dealing with bills:

"In our home, I don't do it, but my husband does" (group A). 
There are also contradictory situations in this connection:

"I really don't like doing bank transfers and things, because I do not trust it at all, but then, contradictorily, I buy and sell funds over the Internet" (group C).

In the specific case of personal income tax declarations and doctors' appointments, some do so with resignation because they no longer have the support of their respective banks:

"It is true that there are things about which you have no choice but to do them or to ask for help and someone does it for you" (group B).

Other tasks mentioned are registration and/or enrollment in courses, consultations of bills (electricity, gas, telephone, etc.), and consultation and conduct of bank transactions.

"All banking formalities [...] Banks are more organized

[...] Government is a big black hole" (group D).

In general, they do not find these tasks difficult, although they express some doubts as to whether the digital National I.D. Document is necessary to perform certain tasks and whether these tasks have to be performed online.

Senior citizens prefer fewer menu sections, large fonts, and contrasting colors in the design of the public administration websites

\subsection{Positive aspects of online administrative tasks according to senior citizens}

Convenience is one of the big pluses:

"Well, it's really convenient for bank matters" (group C).

In addition, the fact that they are able to perform such tasks online brings them satisfaction:

"[Referring to the completion of the tax declaration] when you do all this and from home and things and you see you didn't have to go to the tax authorities [...] well, in the end it always gives a kind of happy feeling [...]" (group A).

Convenience is often associated with other positive aspects such as the speed of performing the tasks and the consequent saving of time:

"I used to go to the bank, an impressive queue and so on; now I do it, I access it from the computer and make a transfer from one company to another, I pay whatever, I pay taxes to the Town Council" (group C).

With regard to this savings of time, they explain that making appointments in advance is a mechanism that has improved the excess demand for face-to-face transactions with government:

"I think that making appointments in advance on all websites is positive" (group A).

However, they mention the inconvenience of not having a physical document as evidence of the tasks they perform online:

"Well, the only thing to do is to save it, we should have an extra hard drive" (group A).

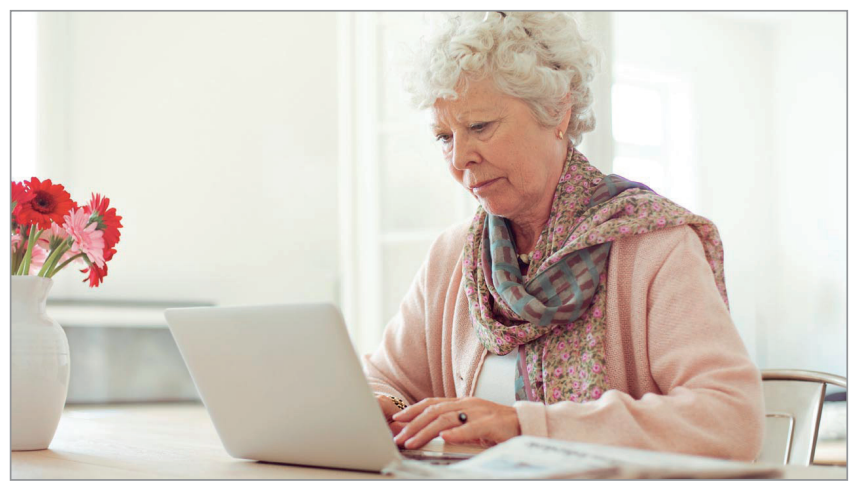

https://goo.gl/jesjur

Thus, there are fears about the intangibility of digital documents.

\subsection{Negative aspects of online administrative tasks according to senior citizens}

In some cases, they point out how inconvenient limited session times are:

"You've spent too much time and then the page tells you you've run out of time" (group A).

Also, they mention that there are some systems of the authorities that they find tiresome:

"It's hard for me to go here, to go on the Papas", it's hard, I don't know why I have to keep changing the password" (group A).

When performing some tasks with certain utility companies (e.g. energy or telecommunications companies) or authorities, they do not trust not having a tangible document with which to back up any error made by their provider:

"send me the paper version, I trust paper more" (Group A).

They are also very cautious about providing some personal data:

"Given all the information there is about pirates on the networks about how you're constantly being pirated and that they're taking your personal data" (group A).

They point to the feeling that

"they've totally got their eye on us" (group C).

and

"you really see that they're following you and that they know exactly who you are, where you are, and what your job is, which makes me quite scared" (group C).

Some participants even express more confidence in private companies than in government:

“Government doesn't fill me with confidence at all [...] giving my data to the government website fills me with less confidence than shopping on Amazon, believe it or not" (group B).

Another negative aspect of e-government is the need for different passwords that you then cannot remember or you mix up:

"It's crazy and every single thing has its password" (group C), as well as the use of highly technical langua- 
ge: "the pages aren't clear, they don't use the language that the average Spaniard uses" (group B).

They also have difficulties understanding some of the content and the unnecessary number of questions required to perform some steps of the tasks:

“[...] I'm a little scared. Every time I have to say OK [...] And sometimes the questions make you get it wrong [...] because sometimes you have to say 'no' when you have to say 'yes'”' (group A).

And they stress about the difficulties of navigating the website of the tax and social security authorities:

"The tax authorities are difficult",

"I'll give another zero to Social Security" (group B).

and the errors in the system:

"whenever I've tried to contact the authorities I haven't managed to do so" (group D)."

The obligation of having to perform some formalities online is another perceived drawback, along with the possibility that telephone calls and direct contact with businesses could disappear:

"the Internet doesn't let me access the company" (group D).

Senior citizens suggest unifying the access data for the various websites of the administrations

\subsection{Characteristics/specifications of the ideal gover- nment website for senior citizens}

In general, they demand websites that are more practical and simple in form and content. From a formal point of view, they point to a reduction in menu sections, with large fonts, and contrasting colors; a minimalist design that makes it easier for them to read and navigate:

"just three or four big clear boxes [...] it should be a simple thing so that you can correctly decipher it" (group A).

From a content perspective, they ask for greater clarity in the messages:

"information should be given very simply because the people who make adverts pester you enough already" (group D).

They also suggest more streamlined processes that do not involve information that is hard to access

"[...] at any given time they ask for [...] information you don't have, and then [...] you have to look for it [...] to make it work" (group A).

They would appreciate some thought regarding time limits on sessions:

"[...] we are slow and we also need to check everything properly" (group A).

Generalizing the difficulty of user names, passwords, codes, and specific data for each page, they determine that it would be convenient to have a common formula that would make it possible to simplify and streamline the formalities in the process:

"I would even have to be the same number [...] you forget passwords [...] I have [...] so many of them" (group A).

However, others demand greater security with personal and renewable passwords

"for that purpose they are very safe in that hackers cannot enter [...] but they are not safe for the user" (group B).

They propose more dialog based pages:

"To be able to write what you want and they answer you" (group B),

"facilitate searches with a richer vocabulary" (group D)

That take into account the needs of citizens:

"But the truth is that they don't hold us normal users in very high esteem" (group B).

Finally, they are fed up of the government asking for data it already has:

"The government often asks you for things they already have" (group A).

For this reason, they suggest greater institutional integration on the Internet to end the lack of co-official administrative status:

"Nothing is connected. It's not a problem of senior citizens but rather of society as a whole" (group D).

Older Internet users express fear of the intangibility of digital documents in the event of possible complaints

\section{Discussion and Conclusions}

This research confirms the progress in the digital empowerment of senior citizens through the performance of various types of activities with government and service providers, sometimes driven by need, but very often by convenience, speed and satisfaction. This affords them greater autonomy (Imserso, 2013, p. 16) and it tends to give this group additional satisfaction, helping foster a positive attitude that "enhances their self-esteem" and optimizes their quality of life "in its psychological dimension and in terms of integration" (Llorente-Barroso; Viñarás-Abad; Sánchez-Valle, 2015, p. 35).

Although such online activities have not been very common tasks among this age group (Agudo-Prado; Pascual-Sevillano; Fombona-Cadavieco, 2012, p. 199; Colesca; Dobrica, 2008), this change ties in with the considerations of Phang et al. (2006) on the conditional use of e-government related to the promotion of self-fulfillment in the successful or satisfying experiences they have had.

With particular regard to online administrative tasks, this research highlights many issues that contribute to a better understanding of their limited use. Indeed, in their conversations, seniors acknowledge that online administrative tasks are not the most common for them, showing that the digital 
divide they experience due to their age is greater in their interaction with e-government (Bélanger; Carter, 2009). However, among senior citizens there is a dynamic of change and a proactive attitude with respect to the use of digital government. The task that is most often performed is the request for doctors' appointments, although some also do their personal income tax declarations, consult bank statements or invoices online, perform bank transfers, and most of them are capable of enrolling in courses.

Among the main positive aspects, they highlight the convenience and speed in doing all these kinds of operations, pointing out the satisfaction and motivation they obtain when able to carry them out without any help from others.

\section{Senior citizens propose clear messages with less content and streamlined pro- cesses that do not involve many steps or questions}

The common anxieties that hinder seniors from having anything to do with e-government include, most notably, the fear that their personal data will be hacked, as well as formal or conceptual issues that prevent them from taking full advantage of websites to perform various tasks. The matters mentioned include:

- limited session times;

- the intangibility of digital files;

- complexity (in design or content) of the web;

- the poor quality of the system used;

- the fear of making errors;

- the superabundance of codes, usernames, and passwords that have to be used;

- the language;

- the possible loss of (real) physical contact when favoring one's online life.

This group proposes simpler websites, in terms of both form and content, with the focus on being practical rather than too detailed, and from a formal standpoint they suggest a limited number of sections, a large legible font, and contrasting colors.

Conceptually, with content in Spanish, clear messages and streamlined processes that do not involve so many steps or so many questions that can cause them to make mistakes.

It would be a question of the authorities seeking to design user-friendly websites in line with the principles of Becker (2005), and Lara-Navarra and Martínez-Usero (2003) to promote the use of digital government among senior citizens, noting that they would avoid advertisements, present clear visual indicators, integrate search engines, download quickly, and would not require precise use of the mouse.

Also, they are asking that the sites of the various institutions or public bodies be coordinated and complementary, so that the various websites do not request data from them that the government already has.

With respect to the limitations of this research it is necessary to clarify that while the proposed method achieves the inten- ded purposes, since it enables an in-depth and first-hand explanation of the reasons for the limited use of e-government and online tasks among senior citizens, some less important aspects might require supplementary treatment, as they are rough outlines that would require greater in-depth study.

In short, the results show that senior citizens with different levels of education demand the use of new technologies (Requena-Hernández; Pastrana-Fidalgo; Salto-Alemany, 2012, p. 17; Montaña; Estanyol; Lalueza, 2015, p. 762) and, therefore, it is essential to consider and create programs that permit their digital empowerment through lifelong media literacy education integrated in training strategies to ensure their social inclusion (Jiménez-López, 2011, AbadAlcalá, 2014).

It would also be advisable that the authorities participate in this process, exploiting the channels of communication depending on the type of operation that citizens wish to perform in order to guide them (Ebbers; Pieterson; Noordman, 2008), and making efforts to mitigate their "technological anxiety" (Phang et al., 2006).

These data suggest the need for social strategies to enable senior citizens to take advantage more often of the Internet for online administrative tasks. This could promote their greater autonomy, allowing them to have an active old age that is adapted to the needs of current society and permits the empowerment of this vulnerable group for the benefit of all citizens and social players.

\section{Notes}

1. Profiles coded according to the European socio-economic classification: http://cordis.europa.eu/result/rcn/88390_en.html

2. Papas is the administrative system used in the Guadalajara Adults School for managing student enrollments.

\section{Acknowledgements}

This paper forms part of and is funded by the Digital Vulnerability Activities Project (HUM2015/HUM-3434 -ProvuldigCAM) of the Madrid Autonomous Region and the European Social Fund. It also forms part of the research project Senior citizens, e-commerce and e-government: Towards bridging the third digital divide (CSO2015-66746-R) of the Research, Development and Innovation Programme addressing the challenges facing society of the Spanish Ministry of Economy and Competitiveness.

\section{Bibliography}

Abad-Alcalá, Leopoldo (2014). “Diseño de programas de einclusión para alfabetización mediática de personas mayores". Comunicar, v. 21, n. 42, pp. 173-180. http://dx.doi.org/10.3916/C42-2014-17

Agudo-Prado, Susana; Pascual-Sevillano, María-Ángeles; Fombona-Cadavieco, Javier (2012). "Usos de las herramientas digitales entre las personas mayores". Comunicar, v. 20, n. 39, pp. 193-201.

https://doi.org/10.3916/C39-2012-03-10

Becker, Shirley-Ann (2005). “E-government usability for older 
adults". Communications of the ACM, v. 48, n. 2, pp. 102-104. https://www.researchgate.net/publication/220422791_Egovernment_usability_for_older_adults

https://doi.org/10.1145/1042091.1042127

Bélanger, France; Carter, Lemuria (2009). "The impact of the digital divide on e-government use". Communications of the ACM, v. 52, n. 4, pp. 132-135.

https://www.researchgate.net/publication/220421422 The_Impact_Of_The_Digital_Divide_On_E-Government_Use https://doi.org/10.1145/1498765.1498801

Callejo-Gallego, Javier (2002). “Observación, entrevista y grupo de discusión: el silencio de tres prácticas de investigación". Revista española de salud pública, v. 76, n. 5, pp. 409-422.

https://doi.org/10.1590/S1135-57272002000500004

Colesca, Sofia E.; Dobrica, Liliana (2008). "Adoption and use of e-government services: the case of Romania". Journal of applied research and technology, n. 3, v. 6, pp. 204-217. http://www.revistas.unam.mx/index.php/jart/article/ view/17623

Ebbers, Wolfgang E.; Pieterson, Willem J.; Noordman, Hans N. (2008). "Electronic government: Rethinking channel management strategies". Government information quarterly, v. 25 , n. 2, pp. 181-201.

https://goo.gl/LBW9rE

https://doi.org/10.1016/j.giq.2006.11.003

Fernández-Ecker, Antonio (2010). “Constitución telemática de empresas". Noticias de la Unión Europea, n. 310, pp. 73-77.

Gibbs, Anita (1997). "Focus groups". Social research update, n. 19. University of Surrey.

http://sru.soc.surrey.ac.uk/SRU19.html

Gil-Flores, Javier; García-Jiménez, Eduardo; Rodríguez-Gómez, Gregorio (1994). "El análisis de los datos obtenidos en la investigación mediante grupos de discusión". Enseñanza, v. 12 , pp. 183-199.

http://e-spacio.uned.es/fez/eserv/bibliuned:20428/ analisis_datos.pdf

Grønkjær, Mette; Curtis, Tine; De-Crespigny, Charlotte; Delmar, Charlotte (2011). "Analysing group interaction in focus group research: Impact on content and the role of the moderator". Qualitative studies, v. 1, n. 2, pp. 16-30.

https://ojs.statsbiblioteket.dk/index.php/qual/article/ viewFile/4273/3706

Imserso (2013). Envejecimiento activo. Libro blanco. Madrid: Imserso.

http://www.imserso.es/InterPresent2/groups/imserso/ documents/binario/8088_8089libroblancoenv.pdf

INE (2010). Instituto Nacional de Estadística. Proyecciones de población a largo plazo 2009-2049. Madrid: INE.

http://www.ine.es/dynt3/inebase/index.htm?type=pcaxis\& path=\%2Ft20\%2Fp270\%2F2009-2049\&file =pcaxis \&L=

INE (2015). Instituto Nacional de Estadística. Resultados nacionales. Utilización de productos TIC por las personas. Madrid: INE.

https://goo.gl/spJqci
Jiménez-López, Juan A. (2011). “Educación en nuevas tecnologías y envejecimiento activo". En: Congreso internacional educación mediática y competencia digital, Segovia. http://www.educacionmediatica.es/comunicaciones/Eje 3/ Juan A. Jiménez López.pdf

Kitzinger, Jenny (1995). "Qualitative research: Introducing focus group". BMJ, v. 7000, n. 311, pp. 299-302.

https://www.ncbi.nlm.nih.gov/pmc/articles/PMC2550365/ pdf/bmj00603-0031.pdf

https://doi.org/10.1136/bmj.311.7000.299

Krueger, Richard A. (1991). El grupo de discusión. Guía práctica para la investigación aplicada: Madrid: Pirámide. ISBN: 8436805895

Lara-Navarra, Pablo; Martínez-Usero, José-Ángel (2002). "Del comercio electrónico a la administración electrónica: tecnologías y metodologías para la gestión de información". El profesional de la información, v. 11, n. 6, pp. 421-435.

http://www.elprofesionaldelainformacion.com/contenidos/2002/ noviembre/2.pdf

Lara-Navarra, Pablo; Martínez-Usero, José-Ángel (2003). "Desarrollo de sitios web para la oferta de servicios característicos de la administración electrónica". El profesional de la información, v. 12, n. 3, pp. 190-199.

http://www.elprofesionaldelainformacion.com/contenidos/2003/ mayo/2.pdf

Llorente-Barroso, Carmen; Viñarás-Abad, Mónica; Sánchez-Valle, María (2015). "Internet and the elderly: Enhancing active ageing". Comunicar, v. 23, n. 45, pp. 29-36.

http://dx.doi.org/10.3916/C45-2015-03

Montañà, Mireia; Estanyol, Elisenda; Lalueza, Ferran (2015). "Internet y nuevos medios: estudio sobre usos y opiniones de los seniors en España". El profesional de la información, v. 24, n. 6, pp. 759-765.

https://doi.org/10.3145/epi.2015.nov.07

Morgan, David L. (1996). "Focus groups". Annual review of sociology, n. 22, pp. 129-152.

https://www.researchgate.net/publication/261773532 Focus_Groups

https://doi.org/10.1146/annurev.soc.22.1.129

Onwuegbuzie, Anthony J.; Dickinson, Wendy B.; Leech, Nancy L.; Zoran, Annmarie G. (2009). "Qualitative framework for collecting and analyzing data in focus group research". International journal of qualitative methods, v. $3, \mathrm{n}$. 8, pp. 1-21.

http://ijq.sagepub.com/content/8/3/1.1.full.pdf+htm/

Phang, Chee-Wei; Sutanto, Juliana; Kankanhalli, AtreyiLi-Yan; Tan, Bernard C. Y.; Teo, Hock-Hai (2006). "Senior citizens' acceptance of information systems: A study in the context of e-government services". IEEE transactions on engineering management, v. 4, n. 53, pp. 555-569.

https://goo.gl/4ZDHQJ

https://doi.org/10.1109/TEM.2006.883710

Powell, Richard A.; Single, Helen M. (1996). "Focus groups". International journal of quality in health care, v. 5, n. 8, pp. 499-504. 
http://intahc.oxfordjournals.org/content/intahc/8/5/499. full.pdf

http://dx.doi.org/10.1093/intqhc/8.5.499

Requena-Hernández, Carmen; Pastrana-Fidalgo, IsabelMaría; Salto-Alemany, Francisco (2012). "Multiplicadores de nuevas tecnologías". Cuadernos de la Cátedra Telefónica (eds.). TIC y envejecimiento de la sociedad, pp. 15-26.

http://catedratelefonica.unileon.es/wp-content/uploads/2015/11/ multiplicadores.pdf

Turner, Phil; Turner, Susan-Ellen; Van-De-Walle, Guy (2007). "How older people account for their experiences with interactive technology". Behaviour \& information technology, v.
26, n. 4, pp. 287-296.

https://goo.gl/fBrTKE

http://dx.doi.org/10.1080/01449290601173499

Vallés, Miguel S. (1997). Técnicas cualitativas de investigación social. Reflexión metodológica y práctica profesional. Madrid: Síntesis. ISBN: 8477384495

http://investigacionsocial.sociales.uba.ar/files/2013/03/ Miguel-Valles-Tecnicas-Cualitativas-De-Investigacion-Social.pdf

Vallés, Miguel S. (2002). Entrevistas cualitativas. Madrid: CIS. ISBN: 9788474763423

http://investigacionsocial.sociales.uba.ar/files/2013/03/ VALLES_Entrevistas-cualitativas.pdf

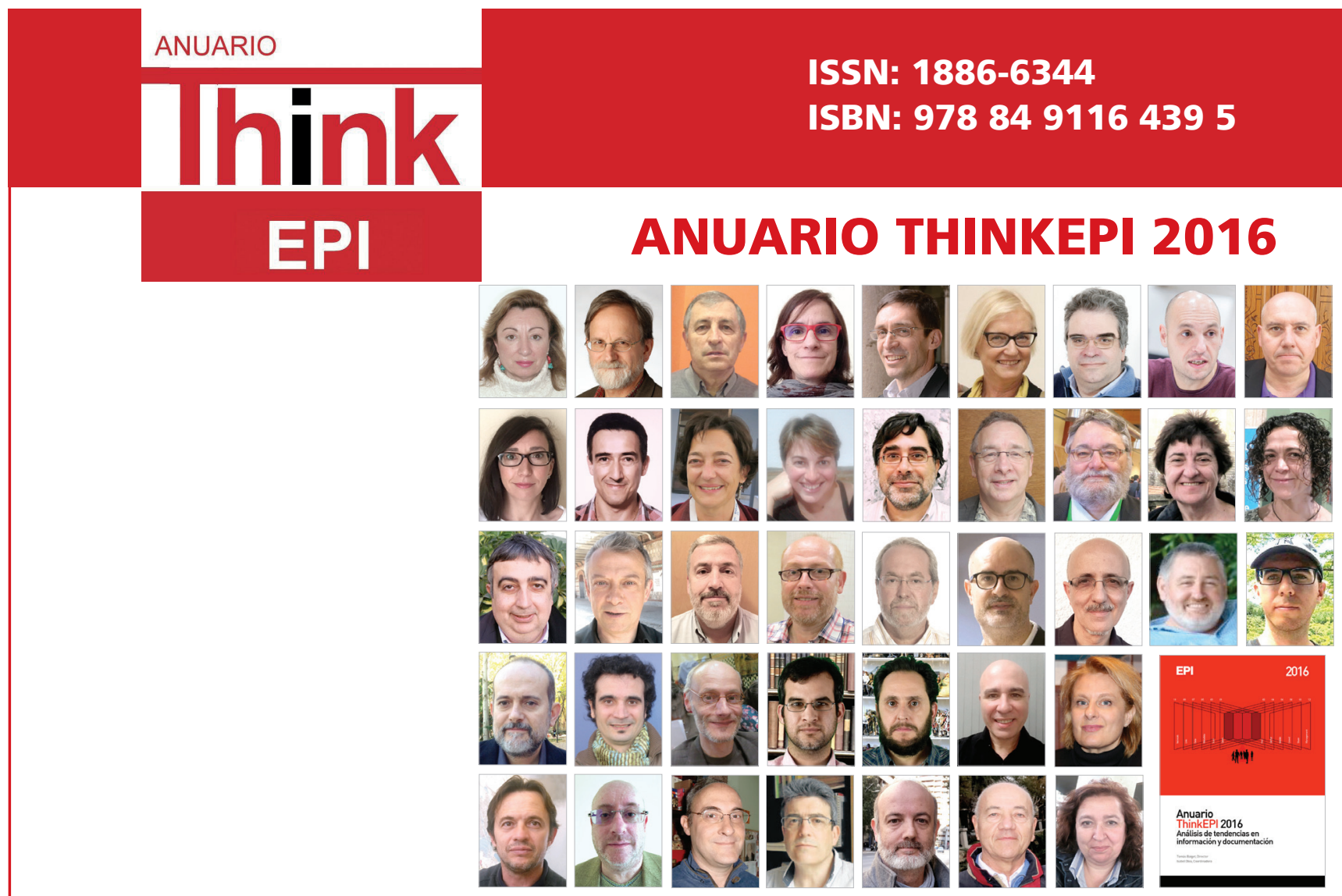

\section{PRECIOS ANUARIO THINKEPI}

Suscripción online (2007-2016)

Instituciones $80 €$

Individuos (particulares) $48 €$

Números sueltos

Instituciones

Anuario ThinkEPI 2016 (pdf) $55 €$

Anuario de ańos anteriores* $30 €$ Individuos (particulares)

Anuario ThinkEPI 2016 (pdf) $30 €$

Anuario de ańos anteriores* $22 €$
Desde 2014 es posible el acceso mediante suscripción a todos los Anuarios ThinkEPI publicados hasta el momento desde el Recyt de la Fecyt

http://recyt.fecyt.es/index.php/ThinkEPI

\author{
Más información: \\ Isabel Olea \\ epi.iolea@gmail.com
}

